Article

\title{
Correction of Hyponatremia May Be a Treatment Stratification Biomarker: A Two-Stage Systematic Review and Meta-Analysis
}

\author{
Francisco Herrera-Gómez ${ }^{1,2, *(0)}$, Diana Monge-Donaire ${ }^{3}$, Carlos Ochoa-Sangrador ${ }^{4}(\mathbb{D}$, \\ Juan Bustamante-Munguira ${ }^{5}$, Eric Alamartine ${ }^{6}$ and F. Javier Álvarez ${ }^{1,7}$ (D) \\ 1 Pharmacology and Therapeutics, Faculty of Medicine, University of Valladolid, Avenida Ramón y Cajal, 7, \\ 47005 Valladolid, Spain; alvarez@med.uva.es \\ 2 Nephrology, Hospital Virgen de la Concha-Sanidad de Castilla y León, 49022 Zamora, Spain \\ 3 Intensive Care Medicine, Hospital Virgen de la Concha-Sanidad de Castilla y León, 49022 Zamora, Spain; \\ dianadonaire@gmail.com \\ 4 Research Unit, Hospital Virgen de la Concha—Sanidad de Castilla y León, 49022 Zamora, Spain; \\ cochoas2@gmail.com \\ 5 Cardiac Surgery, Hospital Clínico Universitario de Valladolid-Sanidad de Castilla y León, \\ 47003 Valladolid, Spain; jbustamantemunguira@gmail.com \\ 6 Nephrology, Dialysis and Transplantation, Centre Hospitalier Universitaire de Saint-Etienne, \\ 42270 Saint-Priest-en-Jarez, France; eric.alamartine@univ-st-etienne.fr \\ 7 CEIm Área de Salud Valladolid Este, Hospital Clínico Universitario de Valladolid-Sanidad de Castilla \\ y León, 47003 Valladolid, Spain \\ * Correspondence: fherrera@med.uva.es; Tel.: +34-983-423-077; Fax: +34-983-423-022
}

Received: 4 August 2018; Accepted: 6 September 2018; Published: 7 September 2018

\begin{abstract}
Changes in serum sodium concentration $\left(\left[\mathrm{Na}^{+}\right]_{\text {serum }}\right)$ can permit evaluation of the treatment effect of vasopressin antagonists (vaptans) in patients with worsening heart failure (HF) or cirrhotic ascites; that is, they may act as a treatment stratification biomarker. A two-stage systematic review and meta-analysis were carried out and contextualized by experts in fluid resuscitation and translational pharmacology (registration ID in the International Prospective Register of Systematic Reviews (PROSPERO): CRD42017051440). Meta-analysis of aggregated dichotomous outcomes was performed. Pooled estimates for correction of hyponatremia (normalization or an increase in $\left[\mathrm{Na}^{+}\right]_{\text {serum }}$ of at least 3-5 mEq/L) under treatment with vaptans (Stage 1) and for clinical outcomes in both worsening HF (rehospitalization and/or death) and cirrhotic ascites (ascites worsening) when correction of hyponatremia is achieved (Stage 2) were calculated. The body of evidence was assessed. Correction of hyponatremia was achieved under vaptans (odds ratio (OR)/95\% confidence interval (95\% CI) / $\mathrm{I}^{2} /$ number of studies (n): 7.48/4.95-11.30/58\%/15). Clinical outcomes in both worsening $\mathrm{HF}$ and cirrhotic ascites improved when correction of hyponatremia was achieved $\left(\mathrm{OR} / 95 \% \mathrm{CI} / \mathrm{I}^{2} / \mathrm{n}\right.$ : $0.51 / 0.26-0.99 / 52 \% / 3)$. Despite the appropriateness of the study design, however, there are too few trials to consider that correction of hyponatremia is a treatment stratification biomarker. Patients with worsening HF or with cirrhotic ascites needing treatment with vaptans, have better clinical outcomes when correction of hyponatremia is achieved. However, the evidence base needs to be enlarged to propose formally correction of hyponatremia as a new treatment stratification biomarker. Markers for use with drugs are needed to improve outcomes related to the use of medicines.
\end{abstract}

Keywords: hyponatremia; biomarkers; drug evaluation; heart failure; ascites 


\section{Introduction}

Hyponatremia is defined as a serum sodium concentration ([Na+ $]_{\text {serum }}$ ) of less than $135 \mathrm{mEq} / \mathrm{L}$ [1]. It is the most common electrolyte abnormality in clinical practice [2]. The understanding of its multifactorial etiology, pathophysiology and clinical presentation are essential in managing patients [3,4].

In the hospital, hypervolemic hyponatremia can be encountered [1], and it appears when water retention exceeds that of sodium. Decompensated heart failure (HF) and cirrhotic ascites episodes are two important causes [2]. Most remarkably, HF and cirrhosis constitute frequent causes of hospitalization [5], and in such patients, hyponatremia is considered as a poor prognostic factor $[5,6]$.

Nevertheless, in both HF and liver cirrhosis patients, hyponatremia reflects a higher activity of arginine vasopressin (AVP), inducing electrolyte-free water retention by binding V2 receptors $[7,8]$. Vaptans, nonpeptide vasopressin-receptor antagonists, increase electrolyte free-water excretion (aquaresis) and, consequently, serum osmolality [9]. Considering that normalization of $\left[\mathrm{Na}^{+}\right]_{\text {serum }}$ is pivotal in HF and advanced cirrhosis, vaptans offer a new treatment approach for these diseases sharing a maladaptive AVP response with the syndrome of inappropriate antidiuretic hormone secretion (SIADH).

Recently, there have been higher expectations that biological processes can be measured and utilized in order to influence clinical decision-making. Nevertheless, several hard issues preventing drug evaluation using biomarkers need to be solved [10]. With the aim to elucidate whether correction of hyponatremia is a treatment stratification biomarker [11], a two-stage systematic review and meta-analysis were performed to summarize the efficacy of the $\mathrm{V}_{1 \mathrm{~A}} / \mathrm{V}_{2}$-receptor antagonist conivaptan [12-15] and the $\mathrm{V}_{2}$-receptor antagonists lixivaptan [16-20], satavaptan [21-23] and tolvaptan [24-36] in relation to changes in $\left[\mathrm{Na}^{+}\right]_{\text {serum }}$ in patients with worsening HF or cirrhotic ascites.

\section{Materials and Methods}

A systematic mapping (Stage 1) followed by an in-depth systematic review (Stage 2) were conducted and reported according to the Preferred Reporting Items for Systematic Reviews and Meta-Analyses (PRISMA) guidelines [37]. A systematic review protocol was developed and registered in the International Prospective Register of Systematic Reviews (PROSPERO) under the following registration ID: CRD42017051440 (final version and revision history of this protocol are available at: http://www.crd.york.ac.uk/PROSPERO/display_record.php?ID=CRD42017051440). A multidisciplinary supervision mechanism provided by an expert advisory group that brought together experts in fluid resuscitation (EA and JB-M) and translational pharmacology (FH-G and FJA) was planned for contextualizing the search findings [38].

Table 1 presents the review question at each of the two planned systematic review stages and the participants, intervention(s)/exposure(s) and comparators being studied. At both stages, randomized controlled trials (RCT), an extension of follow-up of such trials and post-hoc or subgroup analysis of RCTs were requested. The primary outcome was the clinical effect of vaptans in patients with worsening $\mathrm{HF}$ and cirrhotic ascites assessed by changes in $\left[\mathrm{Na}^{+}\right]_{\text {serum. }}$. Secondary outcomes were the correction of hyponatremia (defined as normalization or increase in $\left[\mathrm{Na}^{+}\right]_{\text {serum }}$ of $3-5 \mathrm{mEq} / \mathrm{L}$ or more) and response to therapy with vaptans.

MEDLINE via PubMed, Ovid MEDLINE ${ }^{\circledR}$ and Web of Science, EMBASE via Elsevier's Scopus and The Cochrane Central Register of Controlled Trials (CENTRAL) were searched through October 2017. Database-specific search strategies were developed using terms related to the type of study to be included for both stages, terms related to eligible participants and the intervention for Stage 1 and terms related to medical conditions motivating this study for Stage 2. Searches in electronic databases were supplemented by searching ClinicalTrials.gov and grey literature sources. The DART-Europe E-Theses portal and Open Access Theses and Dissertations (OATD) were interrogated to identify relevant PhD and Master's theses. Manual searches in meeting abstract archives of the Heart Failure Society of America (HFSA) Annual Scientific Meeting 2003-2017, the European Society of Cardiology 
(ESC) Heart Failure congress 2001-2016, the European Association for the Study of the Liver (EASL) The International Liver Congress 2004-2017 and the American Association for the Study of Liver Diseases (AASLD) The Liver Meeting 2001-2017 were conducted to retrieve relevant abstracts. Finally, to ensure literature saturation, a cited reference search of all eligible publications was carried out using Web of Science to identify all studies citing the included studies. The full search strategy is available online at: https://www.crd.york.ac.uk/PROSPEROFILES/51440_STRATEGY_20171218.pdf.

Table 1. Specific stage review questions and study eligibility.

\begin{tabular}{cll}
\hline & \multicolumn{1}{c}{ Systematic Mapping (Stage 1) } & \multicolumn{1}{c}{ In-Depth Meta-Analysis (Stage 2) } \\
\hline Review Question & $\begin{array}{c}\text { Do vaptans have an influence on } \\
\text { hyponatremia } €\end{array}$ & $\begin{array}{l}\text { Is there an association between correction of hyponatremia } \\
\text { \$ under vaptans and improvement of clinical outcomes in } \\
\text { both worsening HF and cirrhotic ascites? }\end{array}$ \\
\hline $\begin{array}{c}\text { Participants/ } \\
\text { Population }\end{array}$ & $\begin{array}{l}\text { Patients with hypervolemic/euvolemic } \\
\text { hyponatremia of diverse causes }\end{array}$ & $\begin{array}{l}\text { Patients with worsening HF or with cirrhotic ascites, } \\
\text { having hyponatremia. }\end{array}$ \\
\hline $\begin{array}{c}\text { Intervention(s)/ } \\
\text { Exposures(s) }\end{array}$ & Vaptans & $\begin{array}{l}\text { Correction of hyponatremia and improvement of the } \\
\text { following clinical outcomes: rehospitalization and/or } \\
\text { death in patients with worsening HF and ascites } \\
\text { worsening in liver cirrhosis patients with ascites. }\end{array}$ \\
\hline Comparators & Placebo/standard care & $\begin{array}{l}\text { No correction of hyponatremia and no clinical } \\
\text { improvement of worsening HF or cirrhotic ascites. }\end{array}$ \\
\hline
\end{tabular}

\footnotetext{
${ }^{\epsilon}$ Hyponatremia: $\left[\mathrm{Na}^{+}\right]_{\text {serum }}<135 \mathrm{mEq} / \mathrm{L} .{ }^{\$}$ Correction of hyponatremia: an increase in $\left[\mathrm{Na}^{+}\right]_{\text {serum }}$ of at least

3-5 mEq/L from Days $2-14$. Abbreviations: $\left[\mathrm{Na}^{+}\right]_{\text {serum, }}$, serum sodium concentration, $\mathrm{HF}$, heart failure.
}

Screening of titles/abstracts and, subsequently, full text report examination of potentially eligible articles were carried out independently and in duplicate by two different reviewer teams formed by CO-S and DM-D for Stage 1 and by DM-D and FH-G for Stage 2. Disagreements were resolved by discussion or referral to a third author (FJA). Corresponding authors of the included studies were contacted whenever possible to retrieve missing information and to confirm study details.

Anonymized datasets corresponding to each of the two stages, describing the characteristics of studies and their participants, interventions, comparators and outcomes recorded in trials eligible, were constructed. Before any analysis, risk of bias was assessed using the standard tool developed by the Cochrane Collaboration [39]. A two-stage meta-analysis of aggregate-level data was planned (CO-S, DM-D and FH-G). The overall odds ratio (OR) and its $95 \%$ confidence interval $(95 \% \mathrm{CI})$ for the outcome of correction of hyponatremia under treatment with vaptans (Stage 1) and for clinical outcomes in both worsening HF (rehospitalization and/or death) and cirrhotic ascites (ascites worsening, defined by either the need for therapeutic paracentesis or an increase in diuretic dosage or weight gain of at least $2 \mathrm{~kg}$ ) when correction of hyponatremia was achieved (Stage 2), were obtained (Mantel-Haenszel random-effect model meta-analysis). Examination of heterogeneity $\left(\mathrm{I}^{2}\right.$ and $\left.\chi^{2}\right)$ and the presence of reporting bias (visual inspection of funnel plots of the estimates against their standard errors) was performed. At Stage 2, calculation of the regression coefficient corresponding to vaptans and the treatment objective of correction of hyponatremia (potential effect modifiers) was attempted (random-effects meta-regression). Review Manager (RevMan) software Version 5.3 (The Cochrane Collaboration, London, UK) was used for meta-analysis, and the 'metareg' macro from Stata Version 12.1 (StataCorp, College Station, TX, USA) was dedicated to meta-regression. A two-staged systematic narrative synthesis with non-quantitative data was also presented [40].

Codependency when combining technologies related to the treatment and the potential biomarker was assessed using an adaptation of Merlin's tool included in the guidelines for preparing a submission to the Pharmaceutical Benefits Advisory Committee (PBAC) from the Department of Health of Australia (CO-S and FH-G) [41,42]. The tool sections of economic evaluation and use of the medicine in practice were not considered. 


\section{Results}

A total of 2075 unique citations were identified throughout the Stage 1 search process. Of these, 25 fulfilled the eligibility criteria [12-36]. Nearly all reports were peer-reviewed journal articles that, in association with two meeting abstracts [19,34], presented the results from 15 RCTs. Out of these trials, the three following were considered eligible for the in-depth systematic review: Satavaptan dose-ranging study in Hyponatremic patients with Cirrhotic AsciTes (HypoCAT) [23], the Acute and Chronic Therapeutic Impact of a Vasopressin antagonist in Congestive Heart Failure (ACTIV in CHF) study [26,27], and the Efficacy of Vasopressin Antagonism in Heart Failure Outcome Study with Tolvaptan (EVEREST) [28-30]. No new reports were identified at the in-depth systematic review search process. At both stages, irrelevant citations were mostly observational studies and opinion narrative reviews. Figure 1 presents the PRISMA flowcharts corresponding to both systematic review stages and the search results obtained [43]. Table 2 shows all eligible studies.

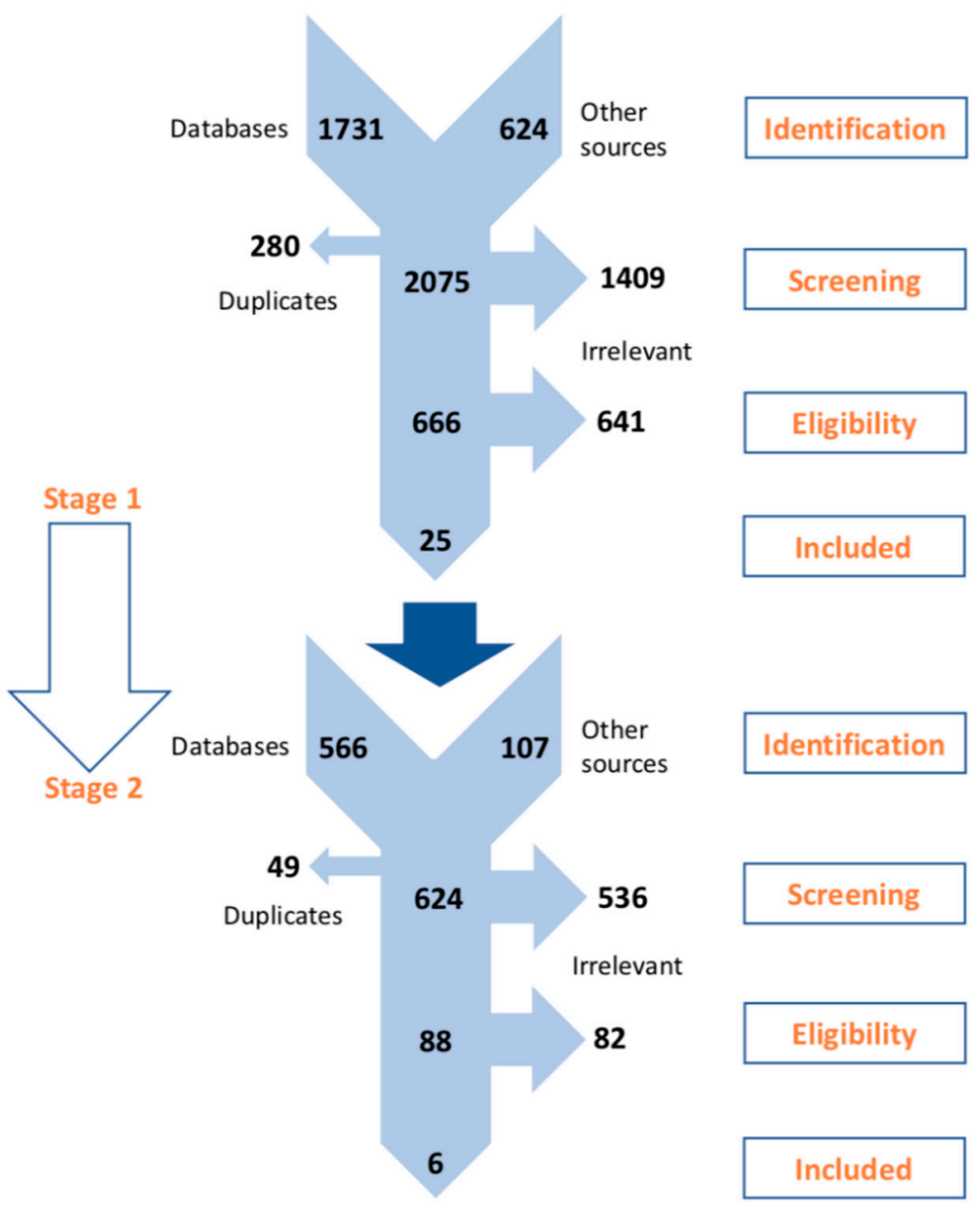

Figure 1. PRISMA flowchart presenting the selection process at the two stages. PRISMA, Preferred Reporting Items for Systematic Reviews and Meta-Analyses. 
Table 2. Participants, interventions, comparators and outcomes in eligible studies.

\begin{tabular}{|c|c|c|c|c|c|c|c|}
\hline Trials Details & Design & Follow-Up & $\begin{array}{c}\text { Participants/Population } \\
\text { Characteristics }\end{array}$ & Interventions (n) & Comparators (n) & Outcomes & Co-Interventions \\
\hline $\begin{array}{l}\text { Conivaptan } \\
\text { Global } \\
\text { [12-15] }\end{array}$ & RCT & $7-9$ days & $\begin{array}{l}\text { Males }(\%) / \geq 65 \text { year }(\%): 52.31 / 68.48 . \\
{\left[\mathrm{Na}^{+}\right]_{\text {serum }}<130 \mathrm{mEq} / \mathrm{lt} .} \\
\text { Causes }(\%): \text { SIADH (51.44), HF/COPD } \\
(32.30) \text {, cancer (11.11), postsurgical (4.47). }\end{array}$ & $\begin{array}{l}\text { Conivaptan } 40 \\
\mathrm{mg} / \text { day }(98) \text { or } 80 \\
\mathrm{mg} / \text { day }(96), \mathrm{IV} / \mathrm{PO} \text {. }\end{array}$ & Placebo (103) & $\begin{array}{l}\text { Day-5 }\left[\mathrm{Na}^{+}\right]_{\text {serum. }} \\
\text { Efficacy outcomes. }\end{array}$ & $\begin{array}{l}\text { Fluid restriction to }<2.0 \mathrm{~L} / 24 \mathrm{~h} \\
\text { Dietary and medication } \\
\text { restrictions. }\end{array}$ \\
\hline $\begin{array}{c}\text { HARMONY } \\
\text { NCT00876798 } \\
\text { Global } \\
{[16]}\end{array}$ & RCT & 24 weeks & $\begin{array}{l}\text { Males }(\%) / \geq 65 \text { year }(\%): 49.70 / 51.42 . \\
{\left[\mathrm{Na}^{+}\right]_{\text {serum }}<135 \mathrm{mEq} / \mathrm{lt}} \\
\text { Causes }(\%) \text { : SIADH ( } 98.00) \text {, cancer }(2.00) .\end{array}$ & $\begin{array}{l}\text { Lixivaptan } 25 \mathrm{mg} \text { plus } \\
\text { dose titration (154). }\end{array}$ & Placebo (52) & Day-7 $\left[\mathrm{Na}^{+}\right]_{\text {serum }}$. & $\begin{array}{l}\text { Fluid restriction (investigator's } \\
\text { discretion). }\end{array}$ \\
\hline $\begin{array}{c}\text { LIBRA } \\
\text { NCT00660959 } \\
\text { Global } \\
{[17]}\end{array}$ & RCT & 30 days & $\begin{array}{l}\text { Males }(\%) / \geq 65 \text { year }(\%): 53.05 / 54.51 . \\
{\left[\mathrm{Na}^{+}\right]_{\text {serum }}<130 \mathrm{mEq} / \mathrm{L}} \\
\text { Causes (\%): SIADH ( } 92.50) \text {, cancer }(7.50) .\end{array}$ & $\begin{array}{l}\text { Lixivaptan } 50 \mathrm{mg} \text { plus } \\
\text { dose titration (54). }\end{array}$ & Placebo (52) & Day-7 $\left[\mathrm{Na}^{+}\right]_{\text {serum. }}$. & $\begin{array}{l}\text { Fluid restriction (investigator's } \\
\text { discretion). }\end{array}$ \\
\hline $\begin{array}{l}\text { VPA } \\
\text { Europe } \\
{[18,19]}\end{array}$ & RCT & 7 days & $\begin{array}{l}\text { Males (\%): } 76.79 . \\
{\left[\mathrm{Na}^{+}\right]_{\text {serum }}<130 \mathrm{mEq} / \mathrm{lt}} \\
\text { Causes (\%): liver cirrhosis (55.29), } \\
\text { SIADH (29.53), HF (13.46). }\end{array}$ & $\begin{array}{l}\text { Lixivaptan } 100 \\
\mathrm{mg} / \text { day (36) or } \\
200 \mathrm{mg} / \text { day }(40)\end{array}$ & Placebo (36) & Day-7 $\left[\mathrm{Na}^{+}\right]_{\text {serum }}$. & Fluid restriction to $<1.0 \mathrm{~L} / 24 \mathrm{~h}$ \\
\hline $\begin{array}{l}\text { VPA-985 } \\
\text { Europe } \\
\text { [20] }\end{array}$ & RCT & 9 days & $\begin{array}{l}\text { Males (\%): } 70.52 . \\
{\left[\mathrm{Na}^{+}\right]_{\text {serum }}<130 \mathrm{mEq} / \mathrm{lt}} \\
\text { Causes (\%): liver cirrhosis (75.00), } \\
\text { HF (13.60), SIADH (11.40). }\end{array}$ & $\begin{array}{l}\text { Lixivaptan } 25 \mathrm{mg} / \text { day } \\
(12), 125 \mathrm{mg} / \text { day (11), } \\
\text { or } 250 \mathrm{mg} / \text { day (10) }\end{array}$ & Placebo (11) & Day-7 $\left[\mathrm{Na}^{+}\right]_{\text {serum }}$. & $\begin{array}{l}\text { Diuretics } \\
\text { Fluid restriction to }<1.5 \mathrm{~L} / 24 \mathrm{~h} \\
\text { Dietary restrictions. }\end{array}$ \\
\hline $\begin{array}{c}\text { DILIPO } \# \\
\text { NCT00274326 } \\
\text { Global } \\
{[21]}\end{array}$ & RCT & 48 weeks & $\begin{array}{l}\text { Males }(\%) / \geq 65 \text { year }(\%): 57.03 / 38.42 . \\
{\left[\mathrm{Na}^{+}\right]_{\text {serum }}<135 \mathrm{mEq} / \mathrm{lt}} \\
\text { Causes }(\%) \text { : HF (76.44), SIADH (17.17), } \\
\text { postsurgical (4.35). }\end{array}$ & $\begin{array}{l}\text { Satavaptan } 25 \\
\mathrm{mg} / \text { day (35) or } \\
50 \mathrm{mg} / \text { day (41). }\end{array}$ & Placebo (42) & $\begin{array}{l}\text { Day-2 }\left[\mathrm{Na}^{+}\right]_{\text {serum }} \\
\text { Efficacy outcomes. }\end{array}$ & Fluid restriction to $<1.5 \mathrm{~L} / 24 \mathrm{~h}$ \\
\hline $\begin{array}{c}\text { Soupart et al., } \\
2006 \\
\text { Europe } \\
{[22]}\end{array}$ & RCT & 12 months & $\begin{array}{l}\text { Males }(\%) / \geq 65 \text { year (\%): 57.03/38.41. } \\
{\left[\mathrm{Na}^{+}\right]_{\text {serum }}<135 \mathrm{mEq} / \mathrm{lt}} \\
\text { Causes (\%): SIADH (85.67), } \\
\text { cancer (14.33). }\end{array}$ & $\begin{array}{l}\text { Satavaptan } 25 \\
\mathrm{mg} / \text { day (14) or } \\
50 \mathrm{mg} / \text { day (12). }\end{array}$ & Placebo (9) & $\begin{array}{l}\text { Day-5 }\left[\mathrm{Na}^{+}\right]_{\text {serum. }} \\
\text { Efficacy outcomes. }\end{array}$ & Fluid restriction to $<1.5 \mathrm{~L} / 24 \mathrm{~h}$ \\
\hline $\begin{array}{c}\text { HypoCAT \& } \\
\text { NCT00501722 } \\
\text { Europe } \\
{[23]}\end{array}$ & $\begin{array}{c}\mathrm{RCT} \\
\mathrm{STR}^{¥}\end{array}$ & 14 days & $\begin{array}{l}\text { Males (\%): } 70.05 . \\
{\left[\mathrm{Na}^{+}\right]_{\text {serum }}<130 \mathrm{mEq} / \mathrm{lt}} \\
\text { Cause: ascites in liver cirrhosis. }\end{array}$ & $\begin{array}{l}\text { Satavaptan } 5 \mathrm{mg} / \text { day } \\
\text { (28), } 12.5 \mathrm{mg} / \text { day (26) } \\
\text { or } 25 \mathrm{mg} / \text { day (28). }\end{array}$ & Placebo (28) & $\begin{array}{l}\text { Day- } 5\left[\mathrm{Na}^{+}\right]_{\text {serum in }} \\
\text { association to clinical } \\
\text { outcomes at Day- } 30 .\end{array}$ & Fluid restriction to $<1.5 \mathrm{~L} / 24 \mathrm{~h}$ \\
\hline $\begin{array}{c}\text { SALT1-SALT2 }^{\dagger} \\
\text { NCT00072683 }^{+} \\
\text {NCT00201994 } \\
\text { Global } \\
{[24,25]}\end{array}$ & RCT & 37 days & $\begin{array}{l}\text { Males (\%): } 58.33 . \\
{\left[\mathrm{Na}^{+}\right]_{\text {serum }}<135 \mathrm{mEq} / \mathrm{lt}} \\
\text { Causes (\%): SIADH (42.70), HF (30.75), } \\
\text { liver cirrhosis (26.55). }\end{array}$ & $\begin{array}{l}\text { Tolvaptan } 15 \mathrm{mg} / \text { day } \\
\text { (225) }\end{array}$ & Placebo (223) & $\begin{array}{l}\text { Day-4 and Day-30 } \\
{\left[\mathrm{Na}^{+}\right]_{\text {serum. }}} \\
\text { Efficacy outcomes. } \\
\end{array}$ & Medication restrictions. \\
\hline
\end{tabular}


Table 2. Cont.

\begin{tabular}{|c|c|c|c|c|c|c|c|}
\hline Trials Details & Design & Follow-Up & $\begin{array}{c}\text { Participants/Population } \\
\text { Characteristics }\end{array}$ & Interventions (n) & Comparators (n) & Outcomes & Co-Interventions \\
\hline $\begin{array}{c}\text { ACTIF in CHF } \\
\text { Global } \\
{[26,27]}\end{array}$ & $\begin{array}{r}\mathrm{RCT} \\
\mathrm{STR}^{¥}\end{array}$ & 60 days & $\begin{array}{l}\text { Males (\%): } 69.10 . \\
{\left[\mathrm{Na}^{+}\right]_{\text {serum }}<135 \mathrm{mEq} / \mathrm{lt}} \\
\text { Cause: HF. }\end{array}$ & $\begin{array}{l}\text { Tolvaptan } 30 \mathrm{mg} / \text { day } \\
(15), 60 \mathrm{mg} / \text { day (22), } \\
\text { or } 90 \mathrm{mg} / \text { day (15). }\end{array}$ & Placebo (16) & $\begin{array}{l}\text { Day-3 }\left[\mathrm{Na}^{+}\right]_{\text {serum in }} \\
\text { association to clinical } \\
\text { outcomes at Day- } 60 .\end{array}$ & HF therapy. \\
\hline $\begin{array}{c}\text { EVEREST }^{\square} \\
\text { NCT00071331 } \\
\text { Global } \\
{[28-30]} \\
\end{array}$ & $\begin{array}{r}\mathrm{RCT} \\
\mathrm{STR}^{¥}\end{array}$ & 60 days & $\begin{array}{l}\text { Males (\%): } 76.48 . \\
{\left[\mathrm{Na}^{+}\right]_{\text {serum }}<135 \mathrm{mEq} / \mathrm{lt}} \\
\text { Cause: } \mathrm{HF} .\end{array}$ & $\begin{array}{l}\text { Tolvaptan } 30 \mathrm{mg} / \text { day } \\
\text { (243) }\end{array}$ & Placebo (232) & $\begin{array}{l}\text { Day-3 }\left[\mathrm{Na}^{+}\right]_{\text {serum in }} \\
\text { association to clinical } \\
\text { outcomes at Day- } 60 .\end{array}$ & HF therapy. \\
\hline $\begin{array}{l}\text { Tolvaptan } \\
\text { USA } \\
\text { [31] }\end{array}$ & RCT & 65 days & $\begin{array}{l}\text { Males (\%): } 57.00 . \\
{\left[\mathrm{Na}^{+}\right]_{\text {serum }}<135 \mathrm{mEq} / \mathrm{lt}} \\
\text { Causes (\%): HF (50.00), SIADH (36.00), } \\
\text { liver cirrhosis }(14.00) .\end{array}$ & $\begin{array}{l}\text { Tolvaptan } 10 \mathrm{mg} / \text { day } \\
\text { plus dose titration } \\
\text { (17). }\end{array}$ & Placebo (11) & $\begin{array}{l}\text { Day-5 }\left[\mathrm{Na}^{+}\right]_{\text {serum }} \cdot \\
\text { Efficacy outcomes. }\end{array}$ & Fluid restriction to $<1.2 \mathrm{~L} / 24 \mathrm{~h}$ \\
\hline $\begin{array}{c}\text { PUMCH }^{\ddagger} \\
\text { NCT00664014 } \\
\text { China } \\
{[32-34]} \\
\end{array}$ & RCT & 7 days & $\begin{array}{l}\text { Males (\%): } 51.11 . \\
{\left[\mathrm{Na}^{+}\right]_{\text {serum }}<135 \mathrm{mEq} / \mathrm{lt}} \\
\text { Causes (\%): HF (59.90), SIADH (40.10). }\end{array}$ & $\begin{array}{l}\text { Tolvaptan } 15 \mathrm{mg} / \text { day } \\
\text { plus dose titration } \\
\text { (56). }\end{array}$ & Placebo (54) & $\begin{array}{l}\text { Day-4 and Day-7 } \\
{\left[\mathrm{Na}^{+}\right]_{\text {serum. }}} \\
\text { Efficacy outcomes. } \\
\end{array}$ & $\begin{array}{l}\text { Fluid restriction (investigator's } \\
\text { discretion). }\end{array}$ \\
\hline $\begin{array}{c}\text { MD Anderson } \\
\text { Cancer Center } \\
\text { NCT01199198 } \\
\text { USA } \\
\text { [35] }\end{array}$ & RCT & 14 days & $\begin{array}{l}\text { Males (\%): } 53.57 . \\
{\left[\mathrm{Na}^{+}\right]_{\text {serum }}<130 \mathrm{mEq} / \mathrm{lt}} \\
\text { Causes (\%): cancer }(89.00), \text { SIADH } \\
(11.00) .\end{array}$ & $\begin{array}{l}\text { Tolvaptan } 15 \mathrm{mg} / \text { day } \\
\text { plus dose titration } \\
\text { (17). }\end{array}$ & Placebo (13) & Day-14 $\left[\mathrm{Na}^{+}\right]_{\text {serum }}$ & $\begin{array}{l}\text { DiureticsFluid restriction to } \\
<1.5 \mathrm{~L} / 24 \mathrm{~h} \text {. }\end{array}$ \\
\hline $\begin{array}{c}\text { Shanmugam et } \\
\text { al., 2015 } \\
\text { CTRI/2013/05/003643 } \\
\text { [36] } \\
\text { India }\end{array}$ & RCT & 30 days & $\begin{array}{l}\text { Males (\%): } 70.70 . \\
{\left[\mathrm{Na}^{+}\right]_{\text {serum }}<135 \mathrm{mEq} / \mathrm{lt}} \\
\text { Cause: } \mathrm{HF} \text {. }\end{array}$ & $\begin{array}{l}\text { Tolvaptan } 15 \mathrm{mg} / \text { day } \\
\text { (25) }\end{array}$ & Placebo (26) & Day-5 $\left[\mathrm{Na}^{+}\right]_{\text {serum }}$ & None \\
\hline
\end{tabular}


Overall, the trials were of moderate quality (Supplementary Table S1). Data from 2238 participants were analyzed. Correction of hyponatremia was achieved after 2-5 days of treatment with vaptans $(59.27 \%)$ and, later, after placebo (18.91\%). Figure 2 shows the calculation of the pooled OR for this treatment objective, which was 7.48 with 95\% CI 4.95-11.30 ( $p<0.00001, \mathrm{I}^{2}=58 \%$ ) [12-34]. Asymmetry in the funnel plot was noted [44].

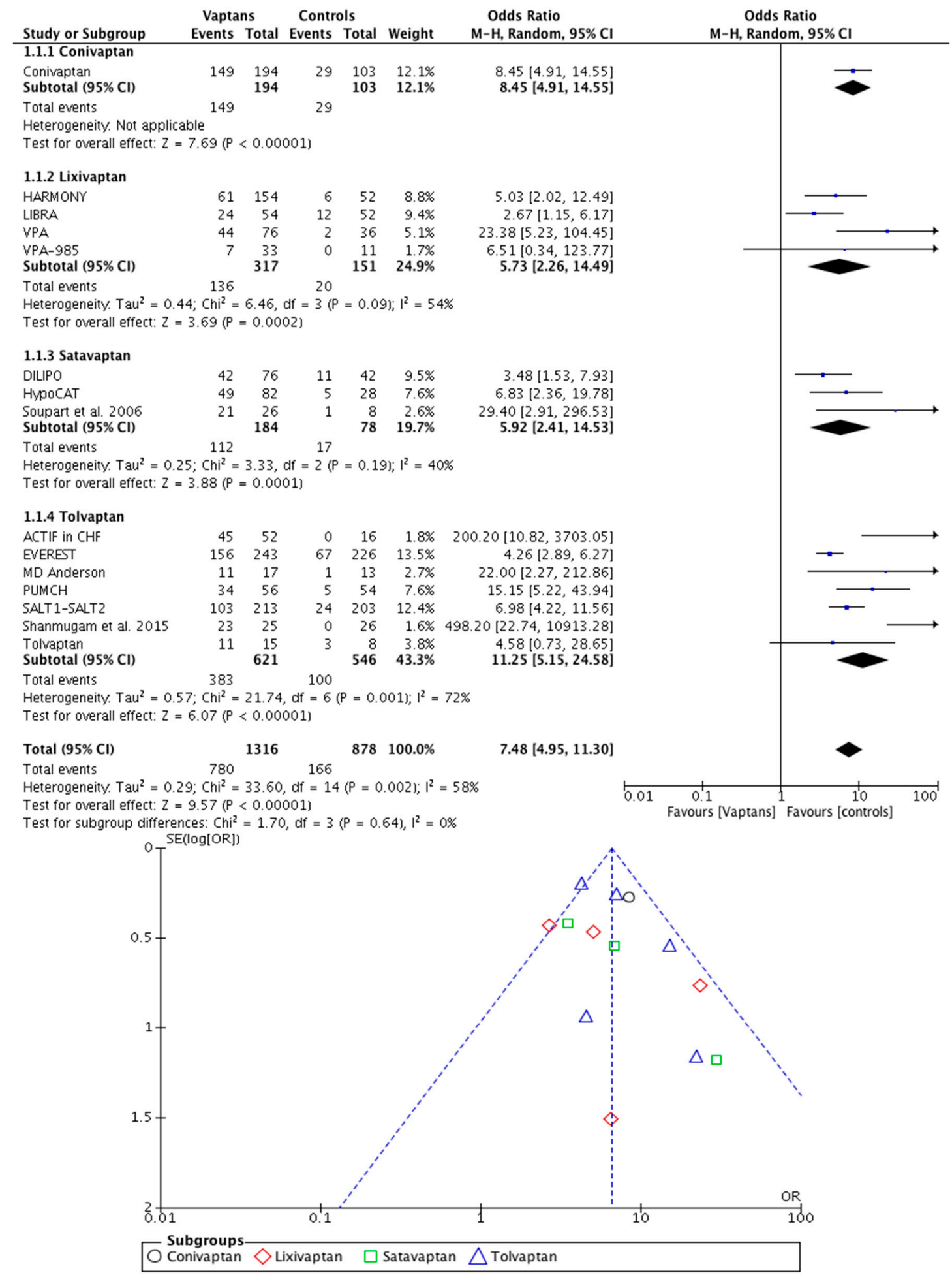

Figure 2. The effect of vaptans on serum sodium concentration. CI, confidence interval; M-H, Mantel-Haenszel test; SE, standard error. 
Rehospitalization and/or death among patients with worsening HF and ascites worsening among liver cirrhosis patients presenting ascites were less frequent in those having achieved correction of hyponatremia, mostly under treatment with vaptans (tolvaptan and satavaptan). The pooled OR was 0.51 with $95 \%$ CI $0.26-0.99\left(p=0.05, I^{2}=52 \%\right.$, Figure 3) [23,26-30]. Meta-regression with tolvaptan and satavaptan, and with correction of hyponatremia, was not possible given the number of studies included [45]. Outcomes were evaluated until 30-60 days of treatment. Only qualitatively, efficacy outcomes (changes in body weight, edema and other endpoints related to electrolyte free-water excretion) improved under vaptans.

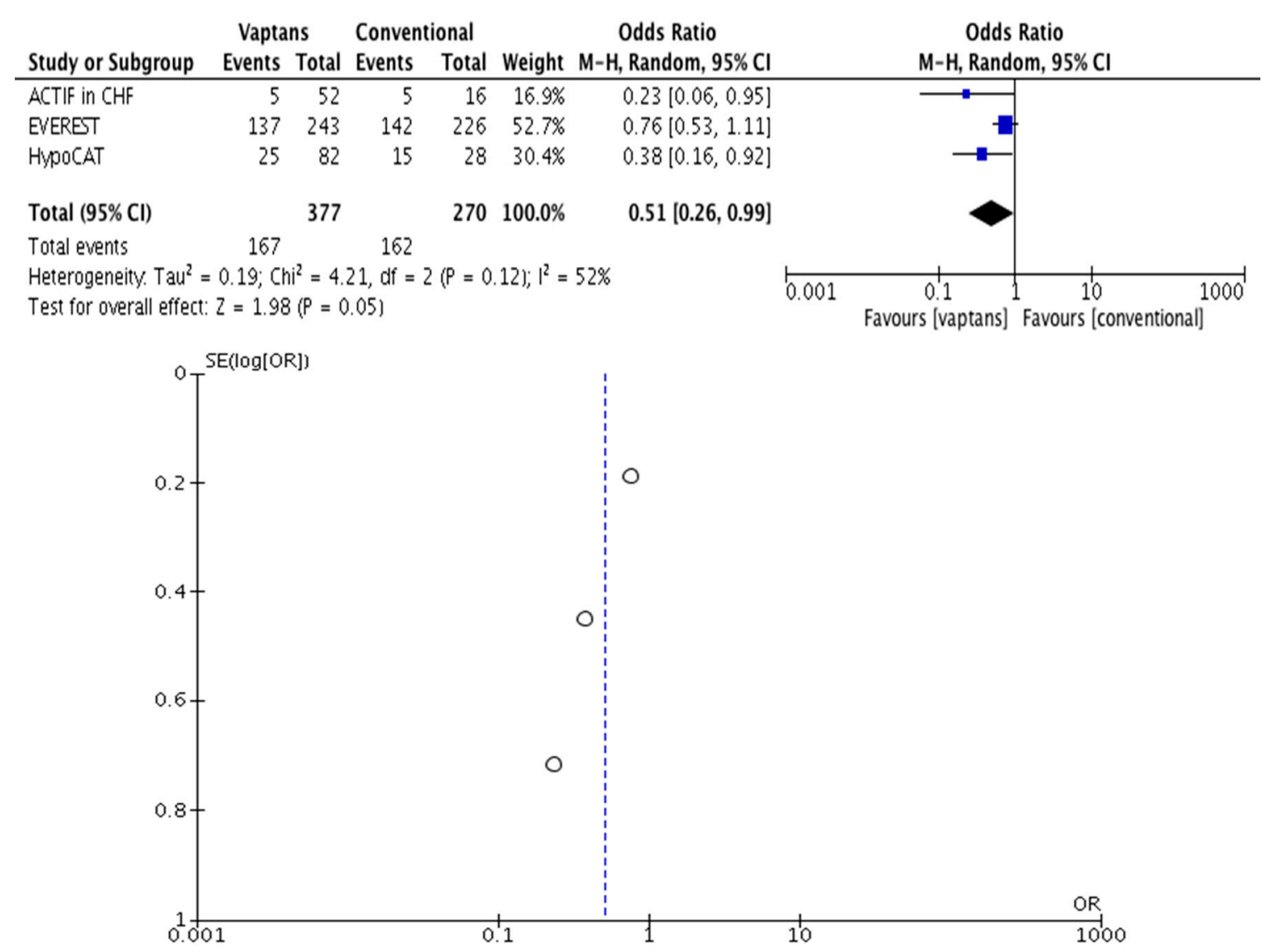

Figure 3. The effect of correction of hyponatremia on clinical outcomes in worsening HF and cirrhotic ascites.

Although it was not clearly specified, the three trials included at Stage 2 used a retrospective biomarker-stratified design, providing low-level direct evidence on codependent health technologies, leading to a benefit from vaptans for patients with worsening HF and cirrhotic ascites (Table 3) [41,42,46].

Table 3. Assessment of codependency when combining the treatment and the biomarker.

\begin{tabular}{ll}
\hline \multicolumn{1}{c}{ Information Requests } & \multicolumn{1}{c}{ Comments } \\
\hline \multicolumn{1}{c}{ Details about the Biomarker, the Test and the Medicine } \\
\hline $1(\mathrm{O})$ Current reimbursement arrangements. & $\begin{array}{l}\text { Changes in }\left[\mathrm{Na}^{+}\right]_{\text {serum }} \text { would permit evaluation of treatment } \\
\text { effect or response to vaptans in patients with worsening HF } \\
\text { or cirrhotic ascites. } \\
\text { Testing is widely available and affordable. }\end{array}$ \\
\hline $2(\mathrm{~T})$ Test sponsor. & $\begin{array}{l}\text { Three methods (flame photometry, indirect and direct } \\
\text { potentiometry) and many sponsors are currently available to } \\
\text { measure sodium levels in serum. }\end{array}$ \\
\hline
\end{tabular}


Table 3. Cont.

\begin{tabular}{|c|c|}
\hline Information Requests & Comments \\
\hline \multicolumn{2}{|c|}{ Section 1 : Context } \\
\hline \multicolumn{2}{|c|}{ Details about the Biomarker, the Test and the Medicine } \\
\hline $3(\mathrm{M})$ Medicine sponsor. & Otsuka: Samsca ${ }^{\circledR}$ (tolvaptan). \\
\hline $4(\mathrm{O})$ Biomarker. & $\begin{array}{l}\text { Correction of hyponatremia: normalization or increase of } \\
{\left[\mathrm{Na}^{+}\right]_{\text {serum }} \text { of at least } 3-5 \mathrm{mEq} / \mathrm{L} \text { after } 2-5 \text { days of treatment }} \\
\text { with vaptans. }\end{array}$ \\
\hline 5 (T) Proposed test. & Determination of serum sodium. \\
\hline $\begin{array}{l}6(\mathrm{O}) \text { Medical condition or problem } \\
\text { being managed. }\end{array}$ & Worsening HF and cirrhotic ascites. \\
\hline 7 (O) Clinical management pathways. & $\begin{array}{l}\text { Decision-making in the management of patients with } \\
\text { worsening HF or cirrhotic ascites under treatment } \\
\text { with vaptans. }\end{array}$ \\
\hline \multicolumn{2}{|c|}{ Rationale for the Codependency } \\
\hline $8(\mathrm{O})$ Definition of the biomarker. & Treatment stratification biomarker. \\
\hline $\begin{array}{l}9(\mathrm{O}) \text { Biological rationale for targeting } \\
\text { that biomarker(s). }\end{array}$ & $\begin{array}{l}\text { Correction of hyponatremia could be associated with } \\
\text { favorable clinical outcomes in patients with worsening HF } \\
\text { and cirrhotic ascites. }\end{array}$ \\
\hline $\begin{array}{l}10(\mathrm{O}) \text { Other biomarker(s) to assess treatment } \\
\text { effect of the medicine. }\end{array}$ & NA \\
\hline $\begin{array}{l}11(\mathrm{O}) \text { Prevalence of the condition being targeted } \\
\text { in the population that is likely to receive the test. }\end{array}$ & The conditions are very prevalent. \\
\hline
\end{tabular}

\section{Proposed Impact of Codependent Technologies on Current Clinical Practice}

12 (T) Consistency of the test results over time.

Clinical outcomes in both worsening HF and cirrhotic ascites improved under the effect of vaptans if correction of hyponatremia was achieved.

13 (T) Use of the proposed test with other treatments and/or for other purposes.

NA

14 (T) Use of the test in the clinical The test is most likely to be an additional test for management pathway. managing patients.

\begin{tabular}{ll}
$15(\mathrm{~T})$ Provision of the test. & The test is in routine use worldwide. \\
\hline $16(\mathrm{~T})$ Specimen or sample collection. & Blood serum
\end{tabular}

17 (T) Use of the test for monitoring purposes (if relevant)

For identifying good and poor responders to vaptans.

18 (O) Availability of other tests for the biomarker. None

\begin{tabular}{c}
\hline Section 2: Clinical Evaluation \\
\hline Direct Evidence Approach \\
\hline
\end{tabular}

Section 2a: Evidence of Prognostic Effect of the Biomarker

19 (O) Prognostic effect of the biomarker. Not assessed.

Section 2d: Clinical Evaluation of the Codependent Technologies (Combined)

$20(\mathrm{O})$ Selection of the direct evidence.

Direct evidence, albeit of a lower level, is provided by retrospective biomarker-stratified RCTs.

$21(\mathrm{O})$ Quality of the direct evidence. Adequate quality.

Item numbers are tagged with $(\mathrm{T}),(\mathrm{M})$ or $(\mathrm{O})$, which indicate whether the item number is relevant to the test, the medicine or overlaps both. Abbreviations: $\left[\mathrm{Na}^{+}\right]_{\text {serum }}$, serum sodium concentration; HF, heart failure; NA, not available; RCT, randomized controlled trial. 


\section{Discussion}

Clinical outcomes in patients with worsening HF or with cirrhotic ascites improved when correction of hyponatremia (normalization or an increase in $\left[\mathrm{Na}^{+}\right]_{\text {serum }}$ of at least $3-5 \mathrm{mEq} / \mathrm{L}$ ) was achieved [23,26-30]. There is a little but adequate evidentiary support that seeks to relate changes in $\left[\mathrm{Na}^{+}\right]_{\text {serum }}$ to treatment with vaptans, leading to the suggestion that correction of hyponatremia may be a new predictive or treatment stratification biomarker.

To date, vaptans have demonstrated an effect on $\left[\mathrm{Na}^{+}\right]_{\text {serum }}[47,48]$, but no systematic review and meta-analysis has confirmed the clinical impact of this effect in both worsening HF [49-53] and cirrhotic ascites [54-56]. Importantly, although these drugs are used after water restriction and diuretics, only some molecules have been studied clinically, and only two vaptans are actually used in the clinic. Therefore, available evidence is limited. In addition, the findings of this study could be interpreted as favoring tolvaptan. However, the summary presented here constitutes an evaluation of the effect of vasopressin-receptor antagonists as a pharmacologic group, and not an analysis of the benefits from only one drug.

Improvement in $\left[\mathrm{Na}^{+}\right]_{\text {serum }}$ can aid the identification of good and poor responders to vaptans. Most remarkably, the evidentiary process of linking biological processes and clinical outcomes under the effect of drugs such that it can be adopted into clinical practice, also called biomarker qualification, is very challenging [10]. In this context, identifying the proper character of the biomarker and whether it is useful for predicting variations in the clinical effect of a medicine or treatment combining medicines (causal relationship) must be known $[41,42,46]$. Eligible trials at Stage 2 used a retrospective biomarker-stratified design; that is, trials randomized eligible participants to vaptans or placebo and measured the effect of treatment in terms of health outcomes (clinical improvement of decompensated HF or cirrhotic ascites) across patient subgroups defined by the biomarker status (correction of hyponatremia) [41,42]. This trial design provides direct evidence, albeit of a lower level, to suggest that correction of hyponatremia may predict the clinical effect of vaptans. However, meta-regression was not possible, so the evidence base needs to be enlarged to propose this treatment objective as a new treatment stratification biomarker for patients.

Recently and at a rapid pace, several biomarkers are appearing [10]. The main purpose is to enable more efficient decision-making by clinicians when facing the patient. From the perspective of health technology assessment (HTA), new markers for use with drugs must be an aid for ascertaining the best medicine for a given disease, as well as the most appropriate doses of this medicine; that is, for personalizing therapies [57]. Transformation of the current health care model, by shifting the focus from a 'one-size-fits-all' system to one that is patient-tailored, must provide clinicians with the right tools to treat the right patient with the right medicine at the right doses, and at the right time.

This two-stage systematic review and meta-analysis have been carried out following a protocol-registered review, which was prospectively updated [37]. Our intention was to prevent changes that can cause reporting biases [58] and to guarantee that our analysis was not a duplicate of previous ones $[59,60]$. Although the purposes at Stage 1 and 2 were different, together both stages were conceived with the intention to provide evidence on the clinical effect of vasopressin-receptor antagonists related to changes in serum sodium concentration. According to our two-stage systematic review design, evidence flowed from wide sources to in-focus sources, such as responses in the bias items of the Quality in Prognosis Studies (QuIPS) tool across the two steps conforming it, which follow the Wortman "mixed-criteria" approach [61]. In addition, the findings were put into context by using a multidisciplinary supervision mechanism, based on an expert advisory group in the topics addressed (fluid resuscitation and translational pharmacology).

This study has limitations. The comprehensiveness of our literature search could not be demonstrated mathematically, due to funnel plot asymmetry [44]. In addition, heterogeneity was large at each of the two stages [62]. However, variability between studies was expected. Sample characteristics (distinct molecules and dosages, patients with both hypervolemic and euvolemic hyponatremia at Stage 1, patients with two distinct diseases at Stage 2) can explain the statistical 
heterogeneity [63] that even increases in the tolvaptan subgroup (Stage 1) [64]. Finally, it should not be forgotten that only three RCTs were eligible at Stage 2, which may be a rationale for including observational studies. Observational evidence may provide moderate to high strength evidence in systematic reviews, but this is very rare, and it would mostly be indicated in assessing prognosis biomarkers [65].

\section{Conclusions}

In conclusion, our study shows that patients with worsening HF or with cirrhotic ascites, needing a treatment with vaptans, have better clinical outcomes when correction of hyponatremia (normalization or an increase in $\left[\mathrm{Na}^{+}\right]_{\text {serum }}$ of at least $3-5 \mathrm{mEq} / \mathrm{L}$ ) is achieved. Nevertheless, the evidence base needs to be enlarged to propose this treatment objective more formally as a new predictive or treatment stratification biomarker.

From the perspective of HTA, treatment stratification biomarkers must serve to improve outcomes related to the use of medicines. Nevertheless, despite advances, clinical qualification of potential candidates continues to be difficult [10]. Healthcare is changing, and there is an urgent need for targeted or more personalized therapies that, in our opinion, should be specially addressed to the most susceptible patient populations [66].

Supplementary Materials: The following are available online at http:/ /www.mdpi.com/2077-0383/7/9/262/s1: Table S1: Assessment of risk of bias in eligible studies.

Author Contributions: E.A. and F.H.-G. developed the hypothesis and study design. C.O.-S., D.M.-D., F.H.-G. and F.J.Á. performed the literature searches and/or screened the papers. E.A., F.H.-G., F.J.Á. and J.B.-M. formed the expert advisory group. C.O.-S., D.M.-D. and F.H.-G. performed data analyses. All authors contributed to drafting and critical revision of all manuscript versions. D.M.-D. and F.H.-G. are co-first authors.

Funding: This research did not receive any specific grant from funding agencies in the public, commercial or not-for-profit sectors. Nevertheless, edition and publication costs were covered by Consejería de Educación, Junta de Castilla y León, Spain (reference: VA161G18).

Acknowledgments: The authors thank Beatriz Muñoz (Research Unit, Hospital Virgen de la Concha-Sanidad de Castilla y León, Zamora, Spain) and Concepción Tarancón-Maján (Intensive Medicine, Hospital Virgen de la Concha-Sanidad de Castilla y León, Zamora, Spain), who helped coordinate data retrieval.

Conflicts of Interest: The authors declare that they have no conflict of interest.

\section{References}

1. Verbalis, J.G.; Goldsmith, S.R.; Greenberg, A.; Korzelius, C.; Schrier, R.W.; Sterns, R.H.; Thompson, C.J. Diagnosis, evaluation, and treatment of hyponatremia: Expert panel recommendations. Am. J. Med. 2013, 126, S1-S42. [CrossRef] [PubMed]

2. Upadhyay, A.; Jaber, B.L.; Madias, N.E. Incidence and prevalence of hyponatremia. Am. J. Med. 2006, 119, S30-S35. [CrossRef] [PubMed]

3. Rondon-Berrios, H.; Agaba, E.I.; Tzamaloukas, A.H. Hyponatremia: Pathophysiology, classification, manifestations and management. Int. Urol. Nephrol. 2014, 46, 2153-2165. [CrossRef] [PubMed]

4. Buffington, M.A.; Abreo, K. Hyponatremia: A Review. J. Intensive Care Med. 2016, 31, 223-236. [CrossRef] [PubMed]

5. Urso, C.; Brucculeri, S.; Caimi, G. Employment of vasopressin receptor antagonists in management of hyponatraemia and volume overload in some clinical conditions. J. Clin. Pharm. Ther. 2015, 40, 376-385. [CrossRef] [PubMed]

6. Gheorghiade, M.; Rossi, J.S.; Cotts, W.; Shin, D.D.; Hellkamp, A.S.; Piña, I.L.; Fonarow, G.C.; DeMarco, T.; Pauly, D.F.; Rogers, J.; et al. Characterization and prognostic value of persistent hyponatremia in patients with severe heart failure in the ESCAPE Trial. Arch. Intern. Med. 2007, 167, 1998-2005. [CrossRef] [PubMed]

7. Goldsmith, S.R.; Gheorghiade, M. Vasopressin antagonism in heart failure. J. Am. Coll. Cardiol. 2005, 46, 1785-1791. [CrossRef] [PubMed]

8. Ginès, P.; Guevara, M. Hyponatremia in cirrhosis: Pathogenesis, clinical significance, and management. Hepatology 2008, 48, 1002-1010. [CrossRef] [PubMed] 
9. Robertson, G.L. Vaptans for the treatment of hyponatremia. Nat. Rev. Endocrinol. 2011, 7, 151-161. [CrossRef] [PubMed]

10. Bai, J.P.; Bell, R.; Buckman, S.; Burckart, G.J.; Eichler, H.G.; Fang, K.C.; Goodsaid, F.M.; Jusko, W.J.; Lesko, L.L.; Meibohm, B.; et al. Translational biomarkers: From preclinical to clinical a report of 2009 AAPS/ACCP Biomarker Workshop. AAPS J. 2011, 13, 274-283. [CrossRef] [PubMed]

11. Institute of Medicine (IOM). Guidelines, standards, oversight, and incentives needed for biomarker development. In The Promises and Challenges of Improving Detection and Treatment: Cancer Biomarkers; Nass, S.J., Moses, H.L., Eds.; The National Academies Press: Washington, DC, USA, 2007; pp. 73-113.

12. Annane, D.; Decaux, G.; Smith, N.; Conivaptan Study Group. Efficacy and safety of oral conivaptan, a vasopressin-receptor antagonist, evaluated in a randomized, controlled trial in patients with euvolemic or hypervolemic hyponatremia. Am. J. Med. Sci. 2009, 337, 28-36. [CrossRef] [PubMed]

13. Verbalis, J.G.; Zeltser, D.; Smith, N.; Barve, A.; Andoh, M. Assessment of the efficacy and safety of intravenous conivaptan in patients with euvolaemic hyponatraemia: Subgroup analysis of a randomized, controlled study. Clin. Endocrinol. 2008, 69, 159-168. [CrossRef] [PubMed]

14. Zeltser, D.; Rosansky, S.; van Rensburg, H.; Verbalis, J.G.; Smith, N.; Conivaptan Study Group. Assessment of the efficacy and safety of intravenous conivaptan in euvolemic and hypervolemic hyponatremia. Am. J. Nephrol. 2007, 27, 447-457. [CrossRef] [PubMed]

15. Ghali, J.K.; Koren, M.J.; Taylor, J.R.; Brooks-Asplund, E.; Fan, K.; Long, W.A.; Smith, N. Efficacy and safety of oral conivaptan: A V1A/V2 vasopressin receptor antagonist, assessed in a randomized, placebo-controlled trial in patients with euvolemic or hypervolemic hyponatremia. J. Clin. Endocrinol. Metab. 2006, 91, 2145-2152. [CrossRef] [PubMed]

16. Abraham, W.T.; Decaux, G.; Josiassen, R.C.; Yagil, Y.; Kopyt, N.; Thacker, H.P.; Mannelli, M.; Bichet, D.G.; Orlandi, C.; HARMONY Study Group. Oral lixivaptan effectively increases serum sodium concentrations in outpatients with euvolemic hyponatremia. Kidney Int. 2012, 82, 1215-1222. [CrossRef] [PubMed]

17. Abraham, W.T.; Hensen, J.; Gross, P.A.; Bichet, D.G.; Josiassen, R.C.; Chafekar, D.S.; Orlandi, C.; LIBRA Study Group. Lixivaptan safely and effectively corrects serum sodium concentrations in hospitalized patients with euvolemic hyponatremia. Kidney Int. 2012, 82, 1223-1230. [CrossRef] [PubMed]

18. Gerbes, A.L.; Gülberg, V.; Ginès, P.; Decaux, G.; Gross, P.; Gandjini, H.; Djian, J.; VPA Study Group. Therapy of hyponatremia in cirrhosis with a vasopressin receptor antagonist: A randomized double-blind multicenter trial. Gastroenterology 2003, 124, 933-939. [CrossRef] [PubMed]

19. Gross, P.; Decaux, G.; Gerbes, A.; Djian, J. A0621 Treatment of hyponatremia (HYPO) with VPA-985. American Society of Nephrology 32nd Annual Meeting and the 1999 Renal Week. November 1-8, 1999, Miami Beach, Florida, USA. Abstracts. J. Am. Soc. Nephrol. 1999, 10, 1A-867A.

20. Wong, F.; Blei, A.T.; Blendis, L.M.; Thuluvath, P.J. A vasopressin receptor antagonist (VPA-985) improves serum sodium concentration in patients with hyponatremia: A multicenter, randomized, placebo-controlled trial. Hepatology 2003, 37, 182-191. [CrossRef] [PubMed]

21. Aronson, D.; Verbalis, J.G.; Mueller, M.; Krum, H.; DILIPO Investigators. Short- and long-term treatment of dilutional hyponatraemia with satavaptan, a selective arginine vasopressin V2-receptor antagonist: The DILIPO study. Eur. J. Heart Fail. 2011, 13, 327-336. [CrossRef] [PubMed]

22. Soupart, A.; Gross, P.; Legros, J.J.; Alföldi, S.; Annane, D.; Heshmati, H.M.; Decaux, G. Successful long-term treatment of hyponatremia in syndrome of inappropriate antidiuretic hormone secretion with satavaptan (SR121463B), an orally active nonpeptide vasopressin V2-receptor antagonist. Clin. J. Am. Soc. Nephrol. 2006, 1, 1154-1160. [CrossRef] [PubMed]

23. Ginès, P.; Wong, F.; Watson, H.; Milutinovic, S.; del Arbol, L.R.; Olteanu, D.; HypoCAT Study Investigators. Effects of satavaptan, a selective vasopressin $\mathrm{V}(2)$ receptor antagonist, on ascites and serum sodium in cirrhosis with hyponatremia: A randomized trial. Hepatology 2008, 48, $204-213$.

24. Verbalis, J.G.; Adler, S.; Schrier, R.W.; Berl, T.; Zhao, Q.; Czerwiec, F.S.; SALT Investigators. Efficacy and safety of oral tolvaptan therapy in patients with the syndrome of inappropriate antidiuretic hormone secretion. Eur. J. Endocrinol. 2011, 164, 725-732. [CrossRef] [PubMed]

25. Schrier, R.W.; Gross, P.; Gheorghiade, M.; Berl, T.; Verbalis, J.G.; Czerwiec, F.S.; Orlandi, C.; SALT Investigators. Tolvaptan, a selective oral vasopressin V2-receptor antagonist, for hyponatremia. N. Engl. J. Med. 2006, 355, 2099-2112. [CrossRef] [PubMed] 
26. Rossi, J.; Bayram, M.; Udelson, J.E.; Lloyd-Jones, D.; Adams, K.F.; Oconnor, C.M.; Stough, W.G.; Ouyang, J.; Shin, D.D.; Orlandi, C.; et al. Improvement in hyponatremia during hospitalization for worsening heart failure is associated with improved outcomes: Insights from the Acute and Chronic Therapeutic Impact of a Vasopressin Antagonist in Chronic Heart Failure (ACTIV in CHF) trial. Acute Card. Care 2007, 9, 82-86. [CrossRef] [PubMed]

27. Gheorghiade, M.; Gattis, W.A.; O'Connor, C.M.; Adams, K.F., Jr.; Elkayam, U.; Barbagelata, A.; Ghali, J.K.; Benza, R.L.; McGrew, F.A.; Klapholz, M.; et al. Effects of tolvaptan, a vasopressin antagonist, in patients hospitalized with worsening heart failure: A randomized controlled trial. JAMA 2004, 291, 1963-1971. [CrossRef] [PubMed]

28. Hauptman, P.J.; Burnett, J.; Gheorghiade, M.; Grinfeld, L.; Konstam, M.A.; Kostic, D.; Krasa, H.B.; Maggioni, A.; Ouyang, J.; Swedberg, K.; et al. Clinical course of patients with hyponatremia and decompensated systolic heart failure and the effect of vasopressin receptor antagonism with tolvaptan. J. Card. Fail. 2013, 19, 390-397. [CrossRef] [PubMed]

29. Gheorghiade, M.; Konstam, M.A.; Burnett, J.C., Jr.; Grinfeld, L.; Maggioni, A.P.; Swedberg, K.; Udelson, J.E.; Zannad, F.; Cook, T.; Ouyang, J.; et al. Short-term clinical effects of tolvaptan, an oral vasopressin antagonist, in patients hospitalized for heart failure: The EVEREST Clinical Status Trials. JAMA 2007, 297, 1332-1343. [CrossRef] [PubMed]

30. Konstam, M.A.; Gheorghiade, M.; Burnett, J.C., Jr.; Grinfeld, L.; Maggioni, A.P.; Swedberg, K.; Udelson, J.E.; Zannad, F.; Cook, T.; Ouyang, J.; et al. Effects of oral tolvaptan in patients hospitalized for worsening heart failure: The EVEREST Outcome Trial. JAMA 2007, 297, 1319-1331. [CrossRef] [PubMed]

31. Gheorghiade, M.; Gottlieb, S.S.; Udelson, J.E.; Konstam, M.A.; Czerwiec, F.; Ouyang, J.; Orlandi, C.; Tolvaptan Investigators. Vasopressin $\mathrm{v}(2)$ receptor blockade with tolvaptan versus fluid restriction in the treatment of hyponatremia. Am. J. Cardiol. 2006, 97, 1064-1067. [CrossRef] [PubMed]

32. Chen, S.; Zhao, J.J.; Tong, N.W.; Guo, X.H.; Qiu, M.C.; Yang, G.Y.; Liu, Z.M.; Ma, J.H.; Zhang, Z.W.; Gu, F. Randomized, double blinded, placebo-controlled trial to evaluate the efficacy and safety of tolvaptan in Chinese patients with hyponatremia caused by SIADH. J. Clin. Pharmacol. 2014, 54, 1362-1367. [CrossRef] [PubMed]

33. Li, L.; Bai, H.; Zhu, W.L.; Tolvaptan Therapy in Hyponatremia with Heart Failure Collaborative Group. The efficacy and safety of tolvaptan on treating heart failure patients with hyponatremia. Zhonghua Xin Xue Guan Bing Za Zhi 2011, 39, 936-940. [PubMed]

34. Li, L.; Bai, H.; Zhu, W.L. The efficacy and safety of tolvaptan on treating congestive heart failure patients with hyponatremia. Heart 2011, 97, A127. [CrossRef]

35. Salahudeen, A.K.; Ali, N.; George, M.; Lahoti, A.; Palla, S. Tolvaptan in hospitalized cancer patients with hyponatremia: A double-blind, randomized, placebo-controlled clinical trial on efficacy and safety. Cancer 2014, 120, 744-751. [CrossRef] [PubMed]

36. Shanmugam, E.; Doss, C.R.; George, M.; Jena, A.; Rajaram, M.; Ramaraj, B.; Anjaneyan, K.; Kanagesh, B. Effect of tolvaptan on acute heart failure with hyponatremia-A randomized, double blind, controlled clinical trial. Indian Heart J. 2016, 68, S15-S21. [CrossRef] [PubMed]

37. Shamseer, L.; Moher, D.; Clarke, M.; Ghersi, D.; Liberati, A.; Petticrew, M.; Shekelle, P.; Stewart, L.A.; PRISMA-P Group. Preferred reporting items for systematic review and meta-analysis protocols (PRISMA-P) 2015: Elaboration and explanation. BMJ 2015, 350, g7647. [CrossRef] [PubMed]

38. Trivedi, D.; Goodman, C.; Dickinson, A.; Gage, H.; McLaughlin, J.; Manthorpe, J.; Ashaye, K.; Iliffe, S. A protocol for a systematic review of research on managing behavioural and psychological symptoms in dementia for community-dwelling older people: Evidence mapping and syntheses. Syst. Rev. 2013, 2, 70. [CrossRef] [PubMed]

39. Higgins, J.P.; Altman, D.G.; Sterne, J.A. Assessing risk of bias in included studies. In Cochrane Handbook for Systematic Reviews of Interventions, Version 5.1.0; Higgins, J.P.T., Green, S., Eds.; The Cochrane Collaboration: London, UK, 2011.

40. Centre for Reviews and Dissemination. Systematic Reviews: Centre for Reviews and Dissemination's (CRD) Guidance for Undertaking Reviews in Health Care. Available online: www.york.ac.uk/media/crd/ Systematic_Reviews.pdf (accessed on 17 July 2018). 
41. Merlin, T.; Farah, C.; Schubert, C.; Mitchell, A.; Hiller, J.E.; Ryan, P. Assessing personalized medicines in Australia: A national framework for reviewing codependent technologies. Med. Decis. Mak. 2013, 33, 333-342. [CrossRef] [PubMed]

42. Product Type 4-Codependent Technologies. Guidelines for Preparing a Submission to the Pharmaceutical Benefits Advisory Committee (Version 5.0). Available online: https:/ / pbac.pbs.gov.au/content/information/ files/pbac-guidelines-version-5.pdf (accessed on 17 July 2018).

43. Moher, D.; Liberati, A.; Tetzlaff, J.; Altman, D.G.; PRISMA Group. Preferred reporting items for systematic reviews and meta-analyses: The PRISMA statement. PLoS Med. 2009, 6, e1000097. [CrossRef] [PubMed]

44. Terrin, N.; Schmid, C.H.; Lau, J. In an empirical evaluation of the funnel plot, researchers could not visually identify publication bias. J. Clin. Epidemiol. 2005, 58, 894-901. [CrossRef] [PubMed]

45. Thompson, S.G.; Higgins, J.P. How should meta-regression analyses be undertaken and interpreted? Stat. Med. 2002, 21, 1559-1573. [CrossRef] [PubMed]

46. Assessment of Co-Dependent Technologies. Procedural Guidance for the Systematic Evaluation of Biomarker Tests. Decision Support Document Nr. 77; Kisser, A., Zechmeister-Koss, I., Eds.; Ludwig Boltzmann Institute for Health Technology Assessment: Vienna, Austria, 2014; pp. 37-39.

47. Hang, X.; Zhao, M.; Du, W.; Zu, D.; Sun, Y.; Xiang, R.; Yang, J. Efficacy and Safety of Vasopressin Receptor Antagonists for Euvolemic or Hypervolemic Hyponatremia: A Meta-Analysis. Medicine 2016, 95, e3310. [CrossRef]

48. Jaber, B.L.; Almarzouqi, L.; Borgi, L.; Seabra, V.F.; Balk, E.M.; Madias, N.E. Short-term efficacy and safety of vasopressin receptor antagonists for treatment of hyponatremia. Am. J. Med. 2011, 124, 977.e1-977.e9. [CrossRef] [PubMed]

49. Wang, C.; Xiong, B.; Cai, L. Effects of Tolvaptan in patients with acute heart failure: A systematic review and meta-analysis. BMC Cardiovasc. Disord. 2017, 17, 164. [CrossRef] [PubMed]

50. Alskaf, E.; Tridente, A.; Al-Mohammad, A. Tolvaptan for Heart Failure, Systematic Review and Meta-Analysis of Trials. J. Cardiovasc. Pharmacol. 2016, 68, 196-203. [CrossRef] [PubMed]

51. Xiong, B.; Huang, Y.; Tan, J.; Yao, Y.; Wang, C.; Qian, J.; Rong, S.; Deng, S.; Cao, Y.; Zou, Y.; et al. The short-term and long-term effects of tolvaptan in patients with heart failure: A meta-analysis of randomized controlled trials. Heart Fail. Rev. 2015, 20, 633-642. [CrossRef] [PubMed]

52. Yang, C.J.; Yang, J.; Yang, J.; Fan, Z.X. Arginine vasopressin antagonist tolvaptan in the treatment of heart failure: A meta-analysis of randomized controlled trials. Int. J. Clin. Exp. Med. 2015, 8, 22117-22128. [PubMed]

53. Nistor, I.; Bararu, I.; Apavaloaie, M.C.; Voroneanu, L.; Donciu, M.D.; Kanbay, M.; Nagler, E.V.; Covic, A. Vasopressin receptor antagonists for the treatment of heart failure: A systematic review and meta-analysis of randomized controlled trials. Int. Urol. Nephrol. 2015, 47, 335-344. [CrossRef] [PubMed]

54. Yan, L.; Xie, F.; Lu, J.; Ni, Q.; Shi, C.; Tang, C.; Yang, J. The treatment of vasopressin V2-receptor antagonists in cirrhosis patients with ascites: A meta-analysis of randomized controlled trials. BMC Gastroenterol. 2015, 15, 65. [CrossRef] [PubMed]

55. Watson, H.; Jepsen, P.; Wong, F.; Ginès, P.; Córdoba, J.; Vilstrup, H. Satavaptan treatment for ascites in patients with cirrhosis: A meta-analysis of effect on hepatic encephalopathy development. Metab. Brain Dis. 2013, 28, 301-305. [CrossRef] [PubMed]

56. Dahl, E.; Gluud, L.L.; Kimer, N.; Krag, A. Meta-analysis: The safety and efficacy of vaptans (tolvaptan, satavaptan and lixivaptan) in cirrhosis with ascites or hyponatraemia. Aliment. Pharmacol. Ther. 2012, 36, 619-626. [CrossRef] [PubMed]

57. Organisation for Economic Co-operation and Development (OECD). Biomarkers: An Overview of the Opportunities and Challenges. Policy Issues for the Development and Use of Biomarkers in Health. Available online: https: / / www.oecd.org/health/biotech/49023036.pdf (accessed on 17 July 2018).

58. Kirkham, J.J.; Altman, D.G.; Williamson, P.R. Bias due to changes in specified outcomes during the systematic review process. PLoS ONE 2010, 5, e9810. [CrossRef] [PubMed]

59. Moher, D. The problem of duplicate systematic reviews. BMJ 2013, 347, f5040. [CrossRef] [PubMed]

60. Siontis, K.C.; Hernandez-Boussard, T.; Ioannidis, J.P. Overlapping meta-analyses on the same topic: Survey of published studies. BMJ 2013, 347, f4501. [CrossRef] [PubMed]

61. Wortman, P.M. Judging research quality. In The Handbook of Research Synthesis; Cooper, H., Hedges, L.V., Eds.; Russell Sage Foundation: New York, NY, USA, 1994; pp. 97-110. 
62. Higgins, J.P.; Thompson, S.G.; Deeks, J.J.; Altman, D.G. Measuring inconsistency in meta-analyses. BMJ 2003, 327, 557-560. [CrossRef] [PubMed]

63. Thompson, S.G. Why sources of heterogeneity in meta-analysis should be investigated. BMJ 1994, 309, 1351-1355. [CrossRef] [PubMed]

64. Rothwell, P.M. Treating individuals 2. Subgroup analysis in randomised controlled trials: Importance, indications, and interpretation. Lancet 2005, 365, 176-186. [CrossRef]

65. O’Neil, M.; Berkman, N.; Hartling, L.; Chang, S.; Anderson, J.; Motu'apuaka, M.; Guise, J.M.; McDonagh, M.S. Observational evidence and strength of evidence domains: Case examples. Syst. Rev. 2014, 3, 35. [CrossRef] [PubMed]

66. Herrera-Gómez, F.; Asensio-González, M.; González-López, A.; Álvarez, F.J. Effects of Intensive Control of Glycemia on Clinical Kidney Outcomes in Type 2 Diabetes Patients Compared with Standard Control: A Meta-Analysis. Front. Pharmacol. 2017, 8, 845. [CrossRef] [PubMed]

(C) 2018 by the authors. Licensee MDPI, Basel, Switzerland. This article is an open access article distributed under the terms and conditions of the Creative Commons Attribution (CC BY) license (http://creativecommons.org/licenses/by/4.0/). 